\title{
Buffalo Milk Yield, Quality, and Marketing in Different Agro-Climatic Districts of Bangladesh
}

\author{
S.M. Rajiur Rahman ${ }^{1}$, Md. Nurul Islam ${ }^{1, *}$, Md. Harun-ur-Rashid ${ }^{1}$, Nathu Ram Sarker², \\ Mohammad Shohel Rana Siddiki ${ }^{1}$, Md. Zakirul Islam ${ }^{1}$ and Mohammad Ashiqul Islam ${ }^{1}$ \\ ${ }^{1}$ Department of Dairy Science, Bangladesh Agricultural University, Mymensingh-2202, Bangladesh \\ ${ }^{2}$ Bangladesh Livestock Research Institute (BLRI), Savar, Dhaka, Bangladesh
}

\begin{abstract}
The study was aimed at assessing the productive performance of dairy buffalo and milk marketing approaches in different agro-climatic districts of Bangladesh. Three (03) districts of Bangladesh viz. Bhola, Mymensingh, and Dinajpur were chosen from the coastal, river basin and semi-arid region, respectively. A triangulation method of survey was used to collect the data and the components of the triangle were buffalo farms, buffalo farmers and buffalo herdsmen. The investigation duration was twelve (12) months. The study revealed that the highest milk yield $(5 \mathrm{~L} / \mathrm{h} / \mathrm{d}$; $p=0.010$ ) was found in the river basin and semi-arid region. Lactation yield was also recorded double in the river basin and semi-arid districts compared to coastal districts $(p=0.000)$. In the case of lactation length, the river basin buffaloes possessed 33 and $36 \%$ longer than coastal and semi-arid districts, respectively. All the chemical components were found significantly different ( $p \leq 0.050$ ) but fat. Among different agro-climatic districts, about $92 \%$ of milk was traded in the coastal region after meeting the household's need but it was noted that the farmers from the semi-arid region kept more than $21 \%$ of milk for family consumption $(p=0.000)$. The highest unit price $(B D T 72 / L)$ of milk was observed in the river basin district $(p=0.011)$. In conclusion, the current situations of buffalo farming and milk marketing approaches in Bangladesh, varies considerably.
\end{abstract}

Keywords: Agro-climatic, dairy buffalo, milk yield, marketing.

\section{INTRODUCTION}

For years, buffaloes are extensively used for the agricultural production system in Bangladesh. Native buffaloes of Bangladesh belong to the Bubalus bubalis with most of the population are the riverine type with exception of some swamp type in the eastern part of the country. The crosses of Murrah, Nili-Ravi, Surti, and Jaffrabadi are frequently available around the Indian border of Bangladesh due to border migration $[1,2]$. However, the farmers keep buffaloes under extensive, semi-intensive and intensive management systems in coastal, river-basin and semi-arid areas in Bangladesh focus on the production of milk and meat along with drought power. Buffaloes are being considered as less prioritized dairy species in Bangladesh despite their important role in the national economy [3]. It is an important animal resource in the agricultural economy of many tropical and subtropical countries [4].

The world buffalo population (194.29 million) is dominated by Asia, representing 92.52\% (179.75 million) of the total buffalo population $[5,6]$. South Asian countries represent about $79.74 \%$ of buffaloes and the rest of $20.26 \%$ in other countries. In Bangladesh, the total buffalo population is about 1.464 million of which coastal regions possess about $40 \%[1,7]$.

*Address correspondence to this author at the Department of Dairy Science, Bangladesh Agricultural University, Mymensingh-2202, Bangladesh; Tel: +8801712621079; Fax: +880 97 61510; E-mail: mnislamds@yahoo.com
Milk composition is considered as an important attribute for both dairy farmers and the dairy industries with regards to payment and processing quality of the milk, respectively [4]. Milk yield and quality are influenced by different feed regimes, breeds, and environments. Feeding unfavorably affects not only the productivity, health, and welfare of animals, but also the milk composition. According to [6], milk composition attributed to breed, physiology of animal, environment, and management system. It was stated by [7] that various non-genetic factors like stage of lactation, season and parity in Surti buffaloes influenced the milk components. Milk production and reproductive performances of buffaloes are negatively impacted by temperature rise during summer and also by sharp temperature decline in winter. The high temperature causes stress due to increased body heat leading to low heat dissipation from the body surface. High heat load in lactating buffaloes reduces their milk production and shorten the duration of lactation periods [5].

Economic returns from dairy buffaloes depend on its lifetime performance [8]. But the productive performance of buffaloes could not reach it' potential due to inadequate knowledge on husbandry practices, high feed cost and low milk price as those are regarded as first, second and third-ranked problems in Bangladesh with respect to buffalo milk production [9].

There are several investigations in Bangladesh demonstrated productive and reproductive 
performances, and management system of dairy buffalo under the extensive and semi-intensive system. However, to the best of our knowledge, there is very few information available about milk yield and quality under the different agro-climatic conditions as well as their marketing approach. Therefore, the present study was undertaken to envisage the productive performances of dairy buffalo and reveal the current marketing approaches of buffalo milk.

\section{MATERIALS AND METHODS}

\section{Study Areas}

Based on buffalo population density, three districts of Bangladesh viz. Bhola, Mymensingh, and Dinajpur were selected. These districts are from coastal, river basin and semi-arid agro-climatic region of Bangladesh, respectively. Geographical information of the study areas has been depicted in Table 1.

\section{Data Collection}

A triangulation method of survey was used to collect the data. The components of the triangle were buffalo farms, buffalo farmers other than those farms and buffalo herdsmen. A predesigned questioner was used to collect data on milk yield, lactation yield, lactation length, household consumption as well as milk marketing approach from 30 buffalo farms of each selected district. These were cross-checked and validated by using the obtained information from the other two components, buffalo farmers and herdsmen.

\section{Milk Sampling and Chemical Analysis}

Morning milk samples $(15,16$ and 18 individual buffalo samples from coastal, river basin and semi-arid area, respectively) were collected and transferred to the laboratory maintaining a cold chain and placed the samples at $-20{ }^{\circ} \mathrm{C}$ until analyzed. Only the samples from Mymensingh (river basin) were analyzed freshly. The milk composition was analyzed by using a Lactoscan milk analyzer (Milktronic Ltd., Bulgaria). All the samples were analyzed in triplicate.

\section{Statistical Analysis}

One way ANOVA was employed on milk yield, composition, price and use pattern to elucidate the regional variation. Data on milk marketing approach in different districts are presented by using descriptive statistics. For all these, SPSS (version 16) was used.

\section{RESULTS AND DISCUSSION}

\section{Milk Yield}

Variation in daily milk yield, lactation yield, lactation length stage of lactation, and lactation number, of the dairy buffaloes with regards to different agro-climatic districts (ACDs) of Bangladesh are summarized in Table 2. The buffaloes in coastal districts significantly $(p=0.010)$ produce $(2 \mathrm{~L} / \mathrm{h} / \mathrm{d})$ less than half of the milk produced daily by buffaloes in the river basin (5.4 $\mathrm{L} / \mathrm{h} / \mathrm{d})$ and semi-arid district $(5.3 \mathrm{~L} / \mathrm{h} / \mathrm{d} ; \mathrm{p} \geq=0.050)$. Likewise, lactation yield of the river basin and semi-arid buffaloes ranged 1007 - $1085 \mathrm{~L} / \mathrm{h}$ and differ nonsignificantly $(p>0.050)$ but significantly $(p=0.000) 2.3$ times more than that of the coastal buffaloes. However, the lactation length of the buffaloes in the coastal and semi-arid area was statistically found similar (188- 197 $d ; p>0.050$ ), which was $96-105$ days less than that of the buffaloes in river basin district $(p=0.021)$. Milk yield in response to the stage of lactation also showed significant differences among the ACDs. The maximum yield was recorded in the river basin region in all three stages and at the third stage semi-arid area shares the ranking with river basin district. The peak milk yield was

Table 1: Agro-Climatic Information of the Study Areas

\begin{tabular}{|c|c|c|c|}
\hline Items & Bhola (Coastal) & Mymensingh (River Basin) & Dinajpur (Semi-arid) \\
\hline \hline Location & $22.6903^{\circ} \mathrm{N} 90.6525^{\circ} \mathrm{E}$ & $24^{\circ} 34.5^{\prime} \mathrm{N} 90^{\circ} 23.5^{\prime} \mathrm{E}$ & $26^{\circ} 0^{\prime} 0^{\prime \prime} \mathrm{N} 88^{\circ} 35^{\prime} 0^{\prime \prime} \mathrm{E}$ \\
\hline Human population density & $480 / \mathrm{km}^{2}$ & $990 / \mathrm{km}^{2}$ & $560 / \mathrm{km}^{2}$ \\
\hline Type of farm & Extensive and Semi-intensive & Extensive and Semi-intensive & Intensive \\
\hline Buffalo density ${ }^{*} \%$ of total population) & 40 & 30 & 25 \\
\hline Average Temperature $\left({ }^{\circ} \mathrm{C}\right)$ & 27.66 & 26.11 & 79 \\
\hline Relative humidity $(\%)$ & 71 & 76 & Humid subtropical climate \\
\hline Climatic condition & Tropical wet and dry & Tropical wet and dry & 26.11 \\
\hline
\end{tabular}

*Indicates the buffalo density of coastal, river basin and semi-arid regions. Source: [1,7,31]. 
found in the second stage of lactation where the yield endured high from 90 to 180 days and then declines in the later stage of lactation. Notably, the average daily milk yield regarding the stage of lactation was recorded $4.28 \mathrm{~L} / \mathrm{h} / \mathrm{d}$ which is in agreement with the findings of [13]. It is evident that the lactation yield in the crossbred buffalo cows range of 800 to $1000 \mathrm{~L}$ [34]. It is worth to mention that similar results were obtained from the current investigation. Considering the number of lactation, the milk yield was varied among the ACDs. Milk production gradually increased as per the lactation number and the decreasing trend was noted for the advancement of lactation stages. Amongst the ACDs, the length of lactation varied from 188-197 days. The lactation length in dairy buffaloes is speckled from 279282 days which was within the range of our findings (189-294) [9]. In addition, it was found that 286 days of lactation period in a similar type of buffaloes under extensive production system in Mathbaria and Pirozpur which was 290 days in Pathorghata and Barguna districts of Bangladesh [10]. The findings of this study are also supported by $[11,12]$.

\section{Chemical Composition of Milk}

The proximate components of buffalo milk in different agro-climatic districts are presented in Table 3. The results revealed that the total solids (TS), solidsnot-fat (SNF), lactose, protein and ash content significantly differed $(p<0.05)$ among the Agro-Climatic districts (ACDs). The highest TS (17\%) was found in the semi-arid region compared to others. Fat content was found non-significant ( $p>0.05)$ among the ACDs and recorded within the range of 6.5 to $7.5 \%$. A higher fraction of SNF was noted for the semi-arid region and river basin districts which were $1 \%$ higher than the coastal districts. But lactose and ash were found higher in the river basin $(4.92 \%$ and $0.7 \%$, respectively) region. The highest mean value for protein was found in the semi-arid area (4\%) followed by others (3.64$3.72 \%$. The present investigation regarding fat per cent was agreed with [14]. They recorded the fat content of buffalo milk within the range of 7.18 to $8.16 \%$ in Noakhali Sirajgang, Potuakhali and Bagerhat districts which were similar to our results. The protein, lactose, SNF and ash content of buffalo milk collected from different agro-climatic districts might be varied due to different feed regimes, breeds, and environments [13]. On feeding a balanced ration, milk fat increased by $6.3 \%$ to $6.6 \%$ in buffaloes [15]. Besides, the supplementation of minerals to the diet of lactating cows and buffaloes has been reported to enhance milk production and milk composition [16].

\section{Buffalo Milk Marketing Approach and Household Consumption}

The results relevant to milk marketing approach and household consumption were stated in Tables $\mathbf{4}$ and $\mathbf{5}$. The data obtained from milk trading, household consumption and unit price of milk were found significantly different $(p<0.05)$. The highest share of milk trading $(92 \%)$ was found in the coastal region and the second highest in the river basin region. Therefore,

Table 2: Buffalo Milk Yield under Different Agro-Climatic Districts of Bangladesh

\begin{tabular}{|c|c|c|c|c|}
\hline Variables & Coastal $(n=38)$ & River basin $(n=33)$ & Semi-arid $(n=35)$ & p-value \\
\hline Daily milk yield (L/h/d) & $2.18 \pm 0.63^{b}$ & $5.41 \pm 1.92^{\mathrm{a}}$ & $5.25 \pm 1.33^{a}$ & 0.010 \\
\hline Lactation yield (L/h/lactation) & $428.91 \pm 124.28^{b}$ & $1085.16 \pm 568.53^{a}$ & $1007.28 \pm 252.36^{a}$ & 0.000 \\
\hline Lactation Length(day) & $197.44 \pm 29.06^{\mathrm{a}}$ & $293.93 \pm 18.22^{b}$ & $188.67 \pm 13.06^{a}$ & 0.020 \\
\hline \multicolumn{5}{|l|}{ Stage of lactation } \\
\hline First stage ( 1 to 90 days) & $2.38 \pm 0.68^{c}$ & $5.53 \pm 1.24^{\mathrm{a}}$ & $5.29 \pm 1.69^{b}$ & 0.000 \\
\hline Second stage (91 to 180 days) & $2.60 \pm 0.93^{c}$ & $7.23 \pm 1.71^{\mathrm{a}}$ & $6.85 \pm 2.11^{\mathrm{b}}$ & 0.001 \\
\hline Third stage (181 to 270 days) & $1.57 \pm 0.70^{b}$ & $3.47 \pm 0.93^{\mathrm{a}}$ & $3.62 \pm 1.30^{\mathrm{a}}$ & 0.001 \\
\hline \multicolumn{5}{|l|}{ Number of lactation } \\
\hline First & $2.10 \pm 0.71^{c}$ & $3.27 \pm 1.95^{b}$ & $4.80 \pm 1.69^{a}$ & 0.021 \\
\hline Second & $2.22 \pm 0.37^{c}$ & $3.32 \pm 1.89^{b}$ & $5.40 \pm 1.40^{\mathrm{a}}$ & 0.031 \\
\hline Third & $2.02 \pm 0.47^{c}$ & $4.08 \pm 2.00^{b}$ & $5.40 \pm 1.25^{\mathrm{a}}$ & 0.012 \\
\hline Fourth & $2.35 \pm 0.65^{c}$ & $3.84 \pm 2.08^{b}$ & $4.76 \pm 1.13^{a}$ & 0.020 \\
\hline
\end{tabular}

Means with different superscripts are significantly different. $n$, number of observations. 
Table 3: Effect of Different Agro-Climatic Districts of Bangladesh on Buffalo Milk Composition

\begin{tabular}{|c|c|c|c|c|}
\hline Variables (\%) & Coastal area $(n=45)$ & River basin $(n=48)$ & Semi-arid $(n=54)$ & p-value \\
\hline TS & $15.60^{c} \pm 2.55$ & $15.91^{\mathrm{bc}} \pm 1.47$ & $17.08^{a} \pm 1.22$ & 0.050 \\
\hline Fat & $7.30 \pm 2.66$ & $6.55 \pm 1.53$ & $7.55 \pm 1.10$ & 0.100 \\
\hline SNF & $8.30^{b} \pm 0.54$ & $9.35^{a} \pm 0.57$ & $9.43^{\mathrm{a}} \pm 0.32$ & 0.011 \\
\hline Lactose & $4.03^{b} \pm 0.32$ & $4.92^{\mathrm{a}} \pm 0.48$ & $4.60^{\mathrm{ab}} \pm 0.20$ & 0.000 \\
\hline Protein & $3.64^{b} \pm 0.41$ & $3.72^{b} \pm 0.26$ & $4.12^{\mathrm{a}} \pm 0.37$ & 0.051 \\
\hline Ash & $0.62^{b} \pm 0.06$ & $0.70^{\mathrm{a}} \pm 0.07$ & $0.69^{\mathrm{a}} \pm 0.02$ & 0.021 \\
\hline
\end{tabular}

Mean with different superscripts are significantly different. $n$, number of observations.

Table 4: Buffalo Milk Prices and Farmers Household Consumption in Different Agro-Climatic Districts of Bangladesh

\begin{tabular}{|c|c|c|c|c|}
\hline Parameters & $\begin{array}{c}\text { Coastal } \\
(\mathbf{n = 4 5})\end{array}$ & $\begin{array}{c}\text { River basin } \\
(\mathbf{n = 4 5 )}\end{array}$ & $\begin{array}{c}\text { Semi-arid } \\
(\mathbf{n = 5 5 )}\end{array}$ & $\mathbf{p}$-value \\
\hline \hline Milk trading (\%) & $92.00^{\mathrm{b}} \pm 9.73$ & $90.77^{\mathrm{b}} \pm 5.78$ & $78.60^{\mathrm{a}} \pm 12.11$ & 0.021 \\
\hline Household consumption (\%) & $8.00^{\mathrm{a}} \pm 9.73$ & $8.23^{\mathrm{a}} \pm 5.41$ & $21.43^{\mathrm{b}} \pm 12.15$ & 0.001 \\
\hline Unit price (BDT/L) & $55.00^{\mathrm{b}} \pm 9.71$ & $71.96^{\mathrm{c}} \pm 2.83$ & $41.10^{\mathrm{a}} \pm 5.16$ & 0.011 \\
\hline
\end{tabular}

The data represented as Mean $\pm S D$. $n$, number of observations.

Table 5: Milk Marketing Approach in Different Agro-Climatic Districts of Bangladesh

\begin{tabular}{|c|c|c|c|}
\hline Parameters & $\begin{array}{c}\text { Coastal } \\
(\mathbf{n = 4 5 )}\end{array}$ & $\begin{array}{c}\text { River basin } \\
(\mathbf{n = 4 5 )}\end{array}$ & $\begin{array}{c}\text { Semi-arid } \\
(\mathbf{n = 4 5 5 )}\end{array}$ \\
\hline \hline Milk buyer (\%) & Ghosh*(100) & Local market (35) and Ghosh (65) & Local market (100) \\
\hline Milking method (\%) & Hand milking (100) & Hand milking (100) & Hand milking (100) \\
\hline Product manufacturing (\%) & None & None & None \\
\hline Advanced payment (\%) & 57.89 & None & None \\
\hline On-site payment (\%) & 42.11 & None & None \\
\hline Advanced amount (Tk.,000) & $3-10$, & & \\
\hline
\end{tabular}

${ }^{*}$ Ghosh, local term means sweetmeat makers.

rightly, significantly highest household consumption was recorded in semi-arid districts $(21 \%)$. However, maximum milk price (Tk.72.0) was found in the river basin region. All of the farmers sold milk directly to Ghosh in coastal areas. In river basin areas producers sold milk both to the local market and sweetmeat shops but for semi-arid areas it was only the local market. Among the study area, hand milking was found as the sole milking method. As far the milk processing is concerned, the farmers didn't produce milk products in coastal and semi-arid district but $11 \%$ of farmers produced milk products in river basin district. About $58 \%$ of farmers received advance money (BDT 300010000 ) every month from the Ghosh and $42 \%$ farmer practised on-site payment. The higher milk selling price was BDT 72/L for the farmer who didn't take advanced money from Ghosh but the selling price was relatively low (BDT 55/L) who had taken advanced payment in coastal areas. Milk price was comparably low in the case of advanced payment in coastal areas. Milk market was more volatile concerning the farmers who didn't take advanced from Ghosh in coastal areas. The current finding is in agreement with [25] and reported that the price of milk was set below by BDT 55/L in advanced payment. Buffalo rearing in the coastal areas of Bangladesh is highly profitable which a crucial pathway for poverty alleviation [26]. However, even more lower price (BDT 41/L) was found in semi-arid area indicating a poor marketing system there. The cost-benefit ratio was 1.31 [27], indicating that buffalo rearing was profitable in Bangladesh $[9,28]$. A total of $25 \%$ of the cow milk consumed by the household [29] but in our study, home consumption of buffalo milk was varied from $8-21 \%$ of total milk yield. It was reported by 
[30] that milk supply chain in Bangladesh had a mixed picture as milk is not consumed by farm household and maily supplied to the traditional local market $(>80 \%)$. It was also mentioned that farmers sold about $95 \%$ of the milk produced directly to Ghosh, the local market and local sweetmeat shop as well but none to the formal distribution channel [30].

\section{CONCLUSION}

It can be concluded that a considerable variation is prevailing among the selected districts from different agro-climatic regions with regards to milk yield (daily, total lactation, according to stage of lactation and number of lactation) and composition. Milk yield and quality in the different agro-climatic districts varied owe to several factors that could not be altered only by farm management practices. The milk marketing approach, milk price and mode of using milk were also found different among the agro-climatic districts. The amount of milk selling was more than the household consumption in the coastal region. It indicates that buffalo farming was highly emphasized for household income for farmer's livelihoods..

\section{REFERENCES}

[1] Faruque MO, Hasnath MA, Siddique NU. Present status of buffaloes and their productivity. Asia-Australian Journal Animal Science 1990; 3: 287-292. https://doi.org/10.5713/ajas.1990.287

[2] Huque QME, Borghese A. Production potentiality and perspective of buffalo in Bangladesh. In: 15th AAAP Animal Science Congress; 2012; 26-30 November, Thailand, p. 244.

[3] Bilal MQ, Suleman M, Raziq A. Buffalo: black gold of Pakistan. Livestock Research for rural development 2006; 18(9): 140-51.

[4] dos Reis CB, Barreiro JR, Mestieri L, de FelícioPorcionato MA, dos Santos MV. Effect of somatic cell count and mastitis pathogens on milk composition in Gyr cows. BMC Veterinary Research 2013; 9(1): 67.

https://doi.org/10.1186/1746-6148-9-67

[5] FAO. Food and Agricultural Organization. The State of Food and Agriculture 2012

[6] Chakravarty AK. Strategies for genetic improvement of buffaloes through production of quality male germplasm in SAARC countries. Seminar paper presentation in "High Yielding Dairy Buffalo Breed Development in SAARC Countries 2013: SAARC Agriculture Centre, BARC Complex, Farmgate, Dhaka-1215.

DLS. Annual Report on Livestock, Division of Livestock Statistics, Ministry of Fisheries and Livestock, Farmgate, Dhaka, Bangladesh 2015.

[8] Bashir MK, Khan MS, Bhatti SA, lqbal A. Lifetime performance of Nili-Ravi buffaloes in Pakistan. AsianAustralasian Journal of Animal Sciences 2007; 20(5): 661-8. https://doi.org/10.5713/ajas.2007.661

[9] Rahman SR, Islam MN, Harun-ur-Rashid M, Siddiki MS, Islam MA. Dairy buffalo production under intensive system in semi-arid area of Bangladesh. Buffalo Bulletin 2019; 38(1): 83-98.
[10]

Karim MR, Hossain MZ, Islam MR, Parvin MS, Matin MA. Reproductivity, Productivity and Management System of Indigenous Buffalo (Bubalusbubalis) Cows in Coastal Areas of Pirojpur and Borguna District of Bangladesh. Progressive Agriculture 2013; 24(1-2): 117-22. https://doi.org/10.3329/pa.v24i1-2.19113

[11] Faruque MO, Hasnath MA, Siddique NN. Present status of buffaloes and their productivity in Bangladesh. AsianAustralasian Journal of Animal Sciences 1990; 3(4): 287-92. https://doi.org/10.5713/ajas.1990.287

[12] El-Kirabi E. Buffalo population and production in Egypt Buffalo Newsletter 1995; 3: 8.

[13] Yadav SP, Sikka P, Kumar D, Sarkar SK, Pandey A, Yadav PS, Sethi RK. Variation in milk constituents during different parity and seasons in Murrah buffaloes 2013; 83(7): 747-751.

[14] Nahar TN, Alam MK, Akhtar S. Study the assessment of nutritional composition and bacterial load in buffalo milk in some selected areas of Bangladesh. Proceeding of the Annual Research Review Workshop 2012-13.Bangladesh Livestock Research Institute, Savar, Dhaka 1341.

[15] Garg MR, Sherasia PL, Phondba BT, Hossain SA. Effect of feeding a balanced ration on milk production, microbial nitrogen supply and methane emissions in field animals. Animal Production Science 2014; 54(10): 1657-61. https://doi.org/10.1071/AN14163

[16] Khochare AB, Kank VD, Gadegaonkar GM, Salunke SC Strategic supplementation of limiting nutrients to medium yielding dairy animals at field level. In Proceeding of the seventh Animal Nutrition Association conference 2010; p. 30.

[17] Patbandha TK, Ravikala K, Maharana BR, Marandi S, Ahlawat AR, Gajbhiye PU. Effect of season and stage of lactation on milk components of Jaffrabadi buffaloes. The Bioscan 2015; 10(2): 635-8.

[18] Bampidis VA, Nistor E, Skapetas VB, Christodoulou V Chatziplis D, Mitsopoulos I, Lagka V. Effect of parity and calving month on milk production and quality of Greek buffalo (Bubalusbubalis). Scientific Papers Animal Science and Biotechnologies 2012; 45(2): 216-20.

[19] Roy B, Mehla RK, Sirohi SK. Influence of milk yield, parity, stage of lactation and body weight on urea and protein concentration in milk of Murrah buffaloes. Asian-Australasian Journal of Animal Sciences 2003; 16(9): 1285-90. https://doi.org/10.5713/ajas.2003.1285

[20] Bonfatti V, Gervaso M, Coletta A, Carnier P. Effect of parity, days in milk, and milk yield on detailed milk protein composition in Mediterranean water buffalo. Journal of Dairy Science 2012; 95(8): 4223-9. https://doi.org/10.3168/jds.2011-5094

[21] Dubey PC, Suman CL, Sanyal MK, Pandey HS, Saxena MM, Yadav PL. Factors affecting composition of milk of buffaloes. The Indian Journal of Animal Sciences 1997; 67(9).

[22] Looper ML. Factors affecting milk composition of lactating cows 2012

[23] Friggens NC, Ridder C, Løvendahl P. On the use of milk composition measures to predict the energy balance of dairy cows. Journal of Dairy Science 2007; 90(12): 5453-67. https://doi.org/10.3168/jds.2006-821

[24] Chen B, Lewis MJ, Grandison AS. Effect of seasonal variation on the composition and properties of raw milk destined for processing in the UK. Food Chemistry 2014 158: 216-23. https://doi.org/10.1016/j.foodchem.2014.02.118

[25] Raha SK. Value Chain Development for Dairy (Cow and Buffalo) Production in coastal region. Research Report of Microfinance and Technical Support Project, Palli KarmaSahayak Foundation (PKSF), Dhaka, Bangladesh 2010.

[26] Hossain MB, Dev SR. Physiochemical characteristics of various raw milk samples in a selected dairy plant of 
Bangladesh. International Journal of Engineering 2013; (3): 2305-8269.

[27] Rahman SM, Begum JB, Sayeed MA, Hossain M, Alam J. Economics of buffalo production in some selected areas of Bangladesh. Bangladesh Journal of Livestock Resources 2008; 15: 39-46.

[28] Islam S, Nahar TN, Begum J, Deb GK, Khatun M, Mustafa A. Economic Evaluation of Buffalo Production in Selected Regions of Bangladesh. Journal of Stock \& Forex Trading 2017; 5: 3. https://doi.org/10.4172/2168-9458.1000177

[29] Halder SR and Barua P. Dairy production, consumption and marketing in Bangladesh, Research \& Evaluation Division, BRAC, September 2003. Visited on 15 January 2018.

[30] Rabbani MG and Sene M. Dairy and meat sector development of Bangladesh: Strategy and approaches. P 65.
Annual Report. Department of Livestock Services. Farmgate Dhaka 2016-17.

[31] Wikipedia.org/Köppen climate classification (visited 2018 February 03) Available from: https://en.wikipedia.org/wiki/

[32] SPSS Inc. Released in 2007. SPSS for Windows, Version 16.0. Chicago, SPSS Inc.

[33] Suman CL, Saxena MM, Pandey HS, Dubey PC, Rajendra $\mathrm{S}$, Sanyal MK, et al. Some factors affecting milk constituents yield of Murrah buffalo. Indian Veterinary Journal 1998; 75(2): 176-177.

[34] Khan S, Qureshi MS, Ahmad N, Amjed M, Durrani FR Younas M. Effect of pregnancy on lactation milk value in dairy buffaloes. Asian-Australasian Journal of Animal Sciences 2008; 21(4): 523-31. https://doi.org/10.5713/ajas.2008.70349

Received on 05-08-2019

DOI: https://doi.org/10.6000/1927-520X.2019.08.03.2

(C) 2019 Rahman et al.; Licensee Lifescience Global.

This is an open access article licensed under the terms of the Creative Commons Attribution Non-Commercial License (http://creativecommons.org/licenses/by-nc/3.0/) which permits unrestricted, non-commercial use, distribution and reproduction in any medium, provided the work is properly cited. 